\section{Tanganyikan Stratigraphy}

AN authoritative and up-to-date account of the stratigraphy of Tanganyika is now available in English as a result of the work of members of the Tanganyika Geological Survey (Memoir No. 1 : "Summary of the Geology of Tanganyika, Part 1 : Introduction and Stratigraphy", by A. M. Quennell, A. C. M. MeKinlay, and W. G. Aitken, 1956 ; 264 pp., The Government Printer, Dar es Salaam, 20s.). This memoir was prepared in draft in $\mathbf{1 9 5 6}$ and used as the authority for the preparation of Lexique Stratigraphic International, Vol. 4, "Afrique" Fasc. 8c, "Tanganyika" (1957), but has only recently become available owing to delays in publication. Important revisions to the pre-Karroo stratigraphy have been made. The basement complex has for some time been known to contrin rocks of different origins and ages in different areas, and several attempts at subdivision have been made as the structural and metamorphic history of the country has become better known. On the basis of the existing evidence, the present authors have adopted a five-fold subdivision, the systems being named in order of decreasing age the Dodoman, Nyanzian, Kavirondian, Usagaran and Ubendian, KaragweAnkolean, and the Bukoban Systems. The Dodoman System is correlated with the oldest known rocks of Africa, and the uppermost Bukoban is thought to be possibly Eocambrian.

\section{The Institute of Metals}

THE following members have been elected to fil vacancies on the Council of the Institute of Metals with effect from the annual general meeting on March 29, 1960 : President, Sir Ronald Prain, chairman and president, Rhodesian Selection Trust, Ltd.; VicePresidents, Dr. H. M. Finniston, research manager, C. A. Parsons and Sons, Ltd., and H. W. Hignett, assistant managing director, Henry Wiggin and Co., Ltd. ; Ordinary Members of Council, Dr. R. W. K. Honeyeombe, professor of physical metallurgy, University of Sheffield; Dr. Ivor Jenkins, chief metallurgist, Research Laboratories, General Electric Co., Ltd. ; E. Robson, managing director, Manganese Bronze and Brass Co., Ltd.; J. Salter, director, British Aluminium Co., Ltd., and C. Smith, works director, James Booth and Co., Ltd.

\section{Physical Society Exhibition}

THE Physical Society Exhibition will be held at the Royal Horticultural Society's Halls, Westminster, London, S.W.1 (just behind Victoria Street from Artillery Row), from January 18 until 1 p.m. on January 22. The opening ceremony will be performed in the New Hall on January 18, 1960, at 11 a.m., by Mr. A. J. Philpot (chairman of the Exhibition Committee and vice-president of the Physical Society) in the unavoidable absence of the president of the Physical Society. Lectures will be given by Flight Lieut. J. Billingham (R.A.F. Institute of Aviation Medicine) on "Some Reactions of the Human Body to the Stresses of High Performance Flight" on January 18 ; Dr. L. Essen (National Physical Laboratory) on "Atomic Time"; and Dr. D. A. Wright (Research Laboratories of the General Electrie Company, Ltd.) on "Recent Advances in Solid State Physics". The lectures will be at 5.45 p.m. Further information can be obtained from the Society, I Lowther Gardens, Prince Consort Road, London, S.W.7.
University News :

Birmingham

THE title of reader in mathematical physics has been conferred on Dr. J. G. Valatin. Dr. D. A. Bell, reader in electromagnetism, and J. T. Allanson, senior lecturer in electrical engineering, have been appointed joint acting heads of the Department of Electrical Engineering until September 30, 1960, in the absence of Prof. D. G. Tucker, who is on study leave. The University has accepted the offer of Joseph Lucas, Ltd., to finance a Fellowship in the field of metal joining in the Department of Industrial Metallurgy for a period of seven years. Research fellowships have been awarded as follows: Dr. Florence J. Pepper (zoology) ; Prof. L. P. V. Johnson (genetics); M. J. Harrison (physics); and H. Mueller (biochemistry). The following appointments are also announced : Dr. H. B. Griffiths, to be lecturer in pure mathematics from July 1,1960 ; and Dr. J. K. Brown, to be lecturer in chemistry from January 1 , 1960.

Oxford

THE following research grants are announced: from British Petroleum Trading, Ltd., $£ 3,000$ spread over three years for the purpose of continuing a research fellowship in geochemistry; and from the du Pont Company, U.S.A., 3,000 dollars for the year 1960-61, for the support of basic research in the field of theoretical ehemistry in the Institute of Mathematics, under the direction of Prof. C. A. Coulson.

\section{Announcements}

Pror. E. G. Cox, professor of inorganic and struc. tural chemistry in the University of Leeds, is to succeed Sir William Slater as secretary of the Agricultural Research Council on Sir William's retirement next year. Prof. Cox's appointment will take effect from July 1, 1960.

The eleventh Annual Lecture of the Plastics Institute will be delivered by Lord Verulam, who will speak on "The Brink of the Unknown". The meeting will be held in the Reardon Smith Lecture Theatre, National Museum of Wales, Cardiff, on April 7, at 6.30 p.m.

A symposium on Organic-Phosphorus Compounds will be held on January 29 in the Department of Chemical Technology, Bradford Institute of Tech. nology. Those taking part include Dr. B. C. Saunders (University of Cambridge), Dr. D. J. Tuck (University of Nottingham), Dr. C. B. Reese (University of Cambridge), and Dr. A. F. Childs (research director, Albright and Wilson (Mfg.), Ltd.). Further particulars can be obtained from the Registrar, Institute of Technology, Bradford 7.

The Non-Destructive Testing Group of the Institute of Physics will hold a meeting in London during May 2-4 jointly with the Société Française de Métallurgie. The programme will have the general theme of the relationship between structure and physical properties of materials and will include recent advances in non-destructive testing techniques. Further information can be obtained from the Secretary, Institute of Physics, 47 Belgrave Square, London, S.W.1.

Erratum. We regret that in the article entitled "Counter-current Distribution of Proteins in Aqueous Polymer Phase Systems" in Nature of November 7, p. 1465, the blocks for Figs. 2 and 3 have been interchanged; the legends, as printed, stand. 